Review

\title{
Urban Sustainability through Innovative Open Space Design. A Novel Approach to the Regeneration of Historic Open Spaces in Some Eastern European Countries and China
}

\author{
Albert Fekete ${ }^{1, *}$, Katarzyna Hodor ${ }^{2}$ and Daixin Dai ${ }^{3, *}$ \\ 1 Institute of Landscape Architecture, Urban Planning and Garden Art, Hungarian University of Agriculture \\ and Life Sciences, 1118 Budapest, Hungary \\ 2 Chair of Landscape Architecture, Faculty of Architecture, Cracow University of Technology CUT, \\ 31-155 Kraków, Poland; kasiahodor@interia.pl \\ 3 College of Architecture and Urban Planning, Tongji University, Shanghai 200092, China \\ * Correspondence: fekete.albert@uni-mate.hu (A.F.); daidaixin@tongji.edu.cn (D.D.)
}

check for

updates

Citation: Fekete, A.; Hodor, K.; Dai, D. Urban Sustainability through Innovative Open Space Design. A Novel Approach to the Regeneration of Historic Open Spaces in Some Eastern European Countries and China. Earth 2021, 2, 405-423. https://doi.org/10.3390/earth2030024

Academic Editor:

Hariklia D. Skilodimou

Received: 1 June 2021

Accepted: 30 June 2021

Published: 5 July 2021

Publisher's Note: MDPI stays neutral with regard to jurisdictional claims in published maps and institutional affiliations.

Copyright: (C) 2021 by the authors. Licensee MDPI, Basel, Switzerland. This article is an open access article distributed under the terms and conditions of the Creative Commons Attribution (CC BY) license (https:/ / creativecommons.org/licenses/by/ $4.0 /)$.

\begin{abstract}
Looking at the urban development of the past two centuries, we can conclude that engineers and architects have been dominating the field of urban design all over Europe. Architects played the most important role, which became even more significant with the increase of urban development. Beyond the architectural approach, a greater importance had been attributed to ecological aspects of urban planning by the turn of the 20th century as, for example, the advance of the garden city movement illustrates. This article focuses on the review of crucial open-space renewal projects from two Eastern European cities and China. The case studies are used to shed light on the characteristics and historical values of contemporary open-space design, based on innovative and landscape architectural approaches and artistic solutions. The study shows that the original role of urban open spaces was significantly extended during the first decades of the 21st century. The increased needs for representation-commercial, cultural and living functions, and ecological and healthy benefits-led to a multifunctional approach in design and planning. The renewal of the historic urban open spaces is carried out under an integrated framework and a unified goal: the development-oriented heritage conservation. Based on strong economic aspects, the general tendency is clearly positive-in spite of still-existing problematic issues (for instance, the management of public transport or the status of public utilities). In the time of a growing awareness of open-space heritage, this overview tries to depict possible general principles of a long-term renewal strategy built on local identity, heritage values and social sustainability.
\end{abstract}

Keywords: downtown renewal; heritage protection; landscape architecture; urban design; urban planning

\section{Introduction}

Environmental challenges of the past decades, such as global climate change, the issues of urban livability and responsible water management, have played an inevitable role in self-definition and acknowledgment of the landscape architecture profession, raising the value of the overarching, environmentally sensitive work of landscape architects in open-space design as well.

The social context has also changed a lot during the past two decades. Incomes and living standards after the affiliation with the European Union have considerably increased in Eastern European countries, similarly to the economic growth of China starting in the 1990s - a phenomenon especially visible in some industrial and commercial centers such as Shanghai. The social improvements caused a higher social expectation with regard to a livable and loveable urban environment. Issues of environmental quality have come into prominence for urban residents. The need for a natural environment, the 
humanisation of open spaces, and a more environmentally conscious and more innovative urban design have fostered the development of the profession. The creativity enhancement, attractiveness and high artistical quality of open-space renewal also represent important design goals, appreciated by the profession and society. Due to the dynamic urbanisation, it can best be observed in the cases of metropolises and smaller settlements how wide the range of spectrum is for interpreting unique streetscape and townscape. The highest skyscrapers, historic urban districts controlled by strict policies as tourist destinations, development projects and artificial islands advertised as luxury, lookout towers with exceptional panoramas, Ferris wheels, restaurants and accommodations attempting to evoke the rural lifestyle- have all been built with a pursuit of uniqueness regarding the image of the settlement. The same pursuit can be detected in the appreciation of existing local values, in the discovery of the cultural heritage of small communities that stand away from the brilliance of metropolises and in the growing awareness of natural assets [1-7]. The advance of open-space design in Eastern and Central Europe is also due to the accession to the European Union, as several international charters, agreements and recommendations were introduced after 2005, with significant funds for implementation, thus providing resources for the realisation of local projects $[8,9]$.

The global economic and financial context has brought important changes into the life of the cities in the new millennium, opening new dimensions for landscape architecture both at the urban and site level. More attention is paid to the conservation and sustainable use of existing values: the healthy and green urban environment, the reduction of social inequalities, the democratic use of space. Environmentally friendly and energy-efficient transport has also become more important. Bottom-up initiatives mobilising community participation and human capacities are gaining ground as well.

The urban renewal of China can be traced back to the regeneration of Beijing in the 1970s [10]. Having undergone stages of old district reconstruction, historical and cultural protection, small-scale gradual regeneration, and organic urban renewal [11], China has already stepped into the concentrated development period of urban renewal [12], in which the protection of urban culture and the shaping of open spaces are of great importance $[13,14]$. The role of landscape architecture in collaboration, support and expansion among multidisciplines and multiscales is becoming increasingly prominent [15] as well as the relationship between urban renewal, and urban culture and art [16].

As a result of all these changes, the improvement of urban spatial quality, based on the enhancement of historical and ecological values, has become a main developmental aspect of urban governance in Eastern European countries and in China as well [17-23]. In the development process, perspectives of various stakeholders of usually different professional backgrounds must be harmonised according to a planning hierarchy. It is not only standards, but also design codes and related plans that support the coordination of the work of designers, engineers, and the investor. The latest instruments of urban governance are based on processing big data, which requires a knowledge of statistics and software. The results are then published as design manuals for practical application. Regarding the contemporary practice, the growing influence and active participation of citizens requires that the latest design manuals are also suitable for the coordination of and the provision of information to the public. In return for an accessible language, our common knowledge assets are expanding through plenty of data and the expertise of citizens, while administrative processes may become easier through the dissemination of information.

The primary goal of the article is to provide an overview of the background and the approach to professional policy for the contemporary renewal of the cityscape in Hungary, Poland, and China, and the results of this policy. The study intends to highlight the outstanding role the landscape architecture profession has played in the development and implementation of the renovation strategies for the urban open spaces of Budapest (HU), Kraków (PL), and Shanghai (CHI). In the past few decades several scholars and 
professionals have also emphasized the importance of the "landscape approach" in the identification, assessment, protection, and management of historical areas [24-37].

Discussions can be summarized in the aspects of planning and design:

- What role does landscape architecture play in urban regeneration and heritage conservation?

- How can "conservation" and "development" be balanced during the process of urban built heritage renewal, maintaining the uniqueness of different places under the unified planning objective?

- How does an innovative and artistic open-space design approach contribute to the creation of a sustainable urban environment?

The historic open-space renewal case studies provide new ideas for these questions from a landscape perspective. Beyond the successful examples, the summary also concludes the deficiencies of the open-space design projects, the problems to be resolved, and the strategic directions to follow in the future.

\section{Methodology}

\subsection{The Key Role of Historic Open Spaces in the Strategic Development of Cities}

Protection of unique urban character is a key element of the concept, also from the perspective of landscape architecture. The special urban characteristics-such as uniqueness and the adaption to successful patterns [38-40] — provide a unique context to the architectural features and open spaces of the cities. In order to protect the unique character and panoramas, all development projects are assessed in this context. Listed buildings also obtain their real significance in the context of adjacent public spaces and cityscape features. Integrated renewal of the buildings and the related public spaces is therefore an essential criterion for renovation projects.

Quality, unique urban character and preserved historic value have growing importance regarding urban environments. Characteristic streetscapes and appearance make cities more attractive for both visitors and investors, strengthening also their economic position. An urban environment with features of the past preserved and integrated into a contemporary context is a source of inspiration for the citizens, strengthening local identity [41-43]. Budapest has a multilayered natural and built heritage originating from various historical periods, strongly related to the unique topography of the city and acknowledged also with the UNESCO designation of the most important heritage areas. Historic open spaces are also scenes of the life of the city today. Development-oriented heritage conservation therefore makes an integral part of the renovation projects. The Long-term Development Concept for Budapest, 2030 provides general information on the urban development objectives of Budapest. Based on the characteristics of the city, this planning document includes long-term development concepts [44].

Kraków, located in the southern part of Poland, has a well-preserved medieval urban layout. In 1978, the city was included in the UNESCO heritage list, which contains the Old City within the former city walls, the Wawel hill with the castle, and the Kazimierz quarter with the Stradom district. The currently binding Municipal Revitalisation Program was adopted with the resolution of the City Council in 2016 as an Act on municipal selfgovernment. The updated document contains the requirements that had been specified in the Regional Operation Programme for the Małopolska Region for 2014-2020 and the guidelines of the supervising institutions included in operation programmes for 20142020, as defined by the Minister of Development in the section of revitalisation of Kraków. This is the core strategic document outlining the actions oriented at the revitalisation of degraded areas, with special consideration for social, economic, and environmental needs. Additionally, in 2018, a local master plan was adopted for the areas with high landscape value, providing protection for the areas with special natural significance. This area covers 1335 hectares (more than $3 \%$ of the city area). An important document for the protection of the city is the paper "The Directions of the Development and the Management of the green areas in Krakow for 2017-2030", specifying the needs and methods of revitalisation 
of the city area. For the revitalisation, it was necessary to include environmental protection and historic monument protection with the preservation of landscape values and with the application of the local master plans [45].

Starting from the beginning of 1990s, despite many great urban historic open-space renewal practices in China, such as the Dashilar Renovation Project in Beijing [46], the renewal of East Nanjing Road Shopping Pedestrian in Shanghai at the end of the 1990s, and regeneration of the public space of Shanghai Southern Yangpu Waterfront [47] in the past few years, there were still many problems. For example, the lack of consistency between urban renewal projects and the cities' long-term development goals led to constructive destruction of historic spaces or hindered the cities' development, focusing more on the protection of historical architecture itself and ignoring the coordination of its surrounding environment. The overemphasis of "static" historical character protection and the neglect of cultural regeneration led to the archaization of streets [24]. However, the East European experiences from Budapest and Kraków are worth learning from in China.

\subsection{Development Background and Case Studies: Budapest, Kraków, Shanghai}

Important criterion for the selection of the case studies was to include open spaces of different importance, types and scales. At the same time, the message of the realised project was also an important consideration, since the presented projects are playing pioneer roles in the renewal processes of historic urban open spaces in case of the studied locations (Budapest, Kraków, Shanghai). The locations of the case studies are presented in Figure 1.

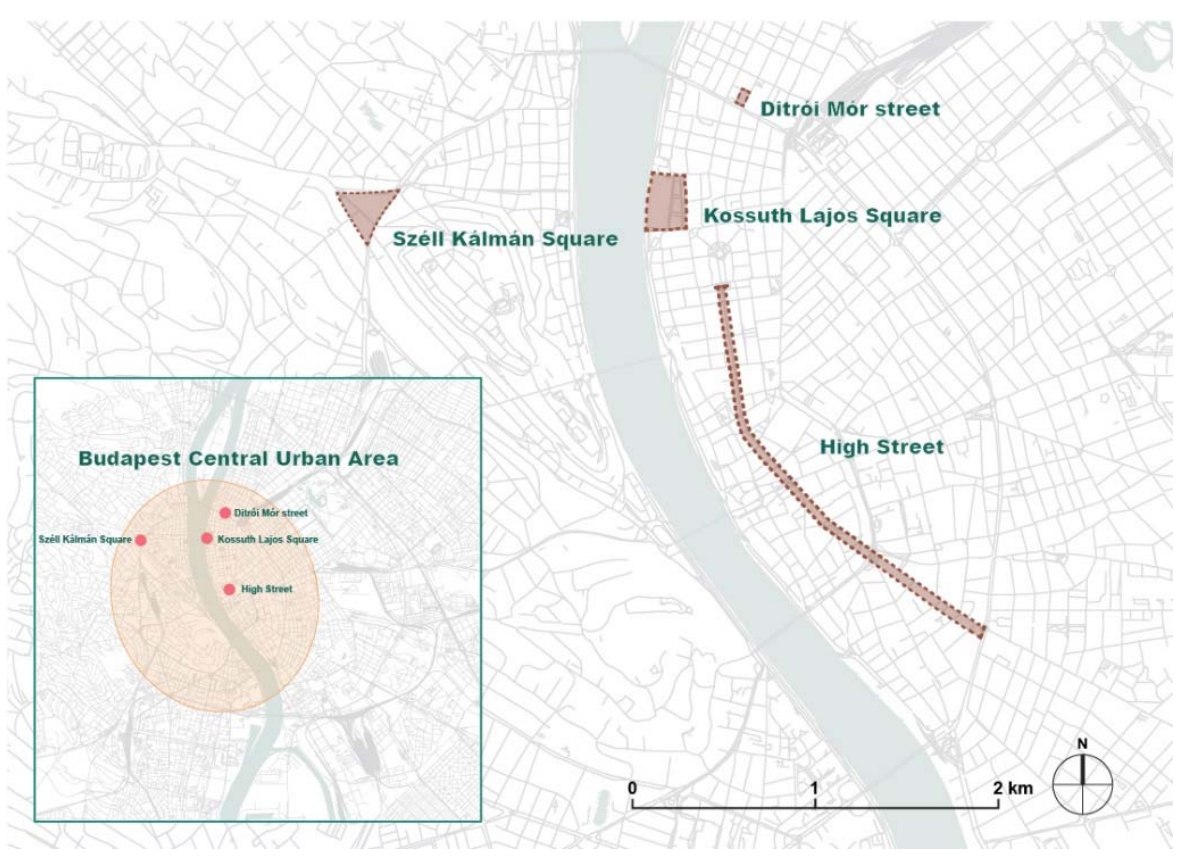

(a)

Figure 1. Cont. 


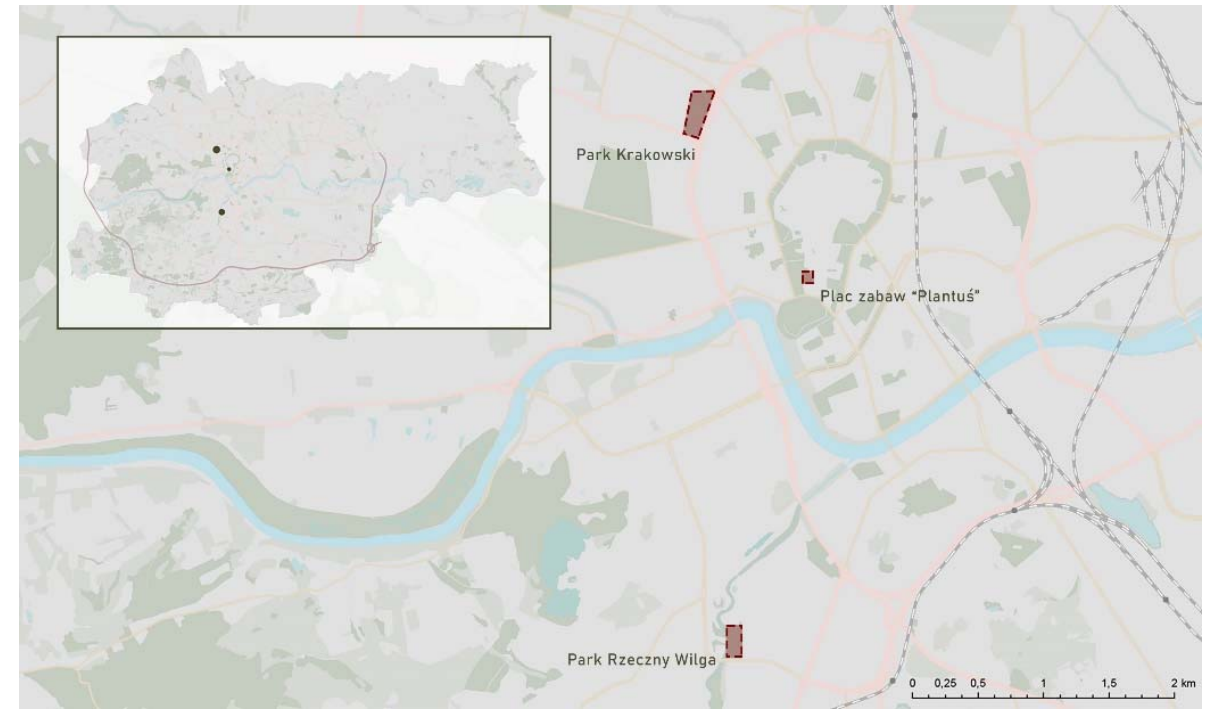

(b)

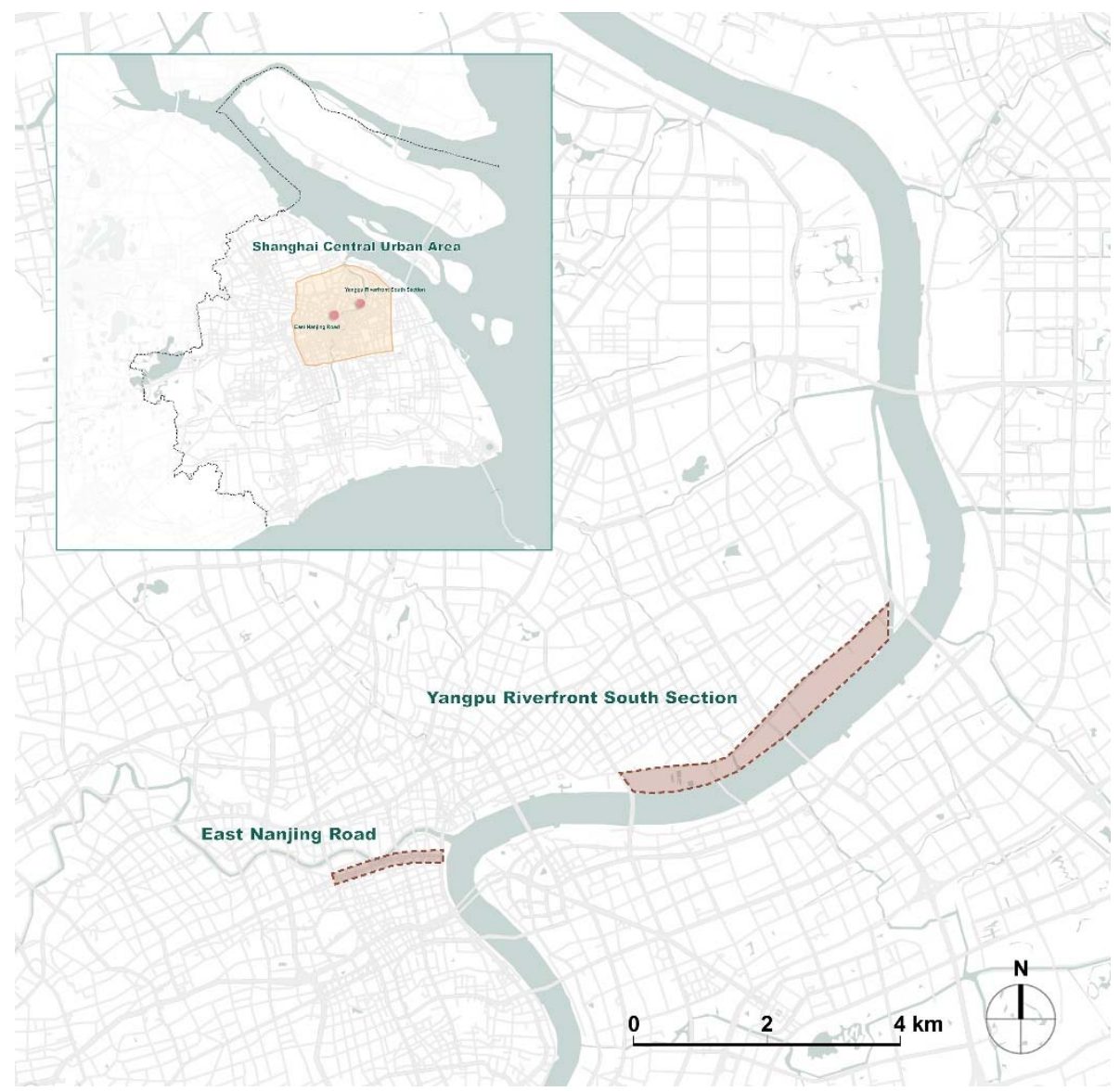

(c)

Figure 1. (a) The location of case studies from Budapest, Hungary. (b) The location of case studies from Kraków, Poland. (c) The location of case studies from Shanghai, China (prepared by the authors). 


\section{Discussion and Results}

The short presentation of the case studies represents the discussions and the main results of this paper.

\subsection{Budapest, Hungary}

The Downtown of Budapest is a priority area of the renovation of historic open spaces, with its public squares renewed through various complex projects during the past 15 years. The objective of a complex renewal of the urban configuration, functional layout and traffic in the Downtown had been approved already in 2005 by the Podmaniczky Programme, Medium-term Urban Development Programme [48]. This provided the basis for the local authority to launch the Heart of Budapest urban development programme and set the main development objectives by March 2008.

Following the Podmaniczky Programme, from 2013 the development of Budapest open spaces was advanced through a call for entries named "TÉR-KÖZ" announced by the Office of Urban Planning at the City Council, boosting the renewal of several public squares and community spaces in the city [49]. Beyond a sensitive approach to heritage conservation and design, "TÉR-KÖZ" projects also explicitly supported local identity, innovative solutions, public participation and sustainability. So far, 113 Budapest public spaces have been renovated within the framework of the programme [50].

Budapest district councils have also recognised that beyond serving transit traffic, quality public places have additional roles to play: they provide grounds for representation, market place, playgrounds, sportgrounds, bar terraces, community gardens, or other community functions. Accordingly, in the past few years, several open-space renovation programmes, initiated by the central government and the local governments of the city and the districts, have been successfully realised or are in progress (Imre Steindl Programme, Downtown Europe Programme, Magdolna Quarter Programme, National Hauszmann Programme, Modern Cities Programme, Corvin-Szigony Project, AngyalZöld Project, RakPark Project, etc.). Since 2010, the renovation of open spaces has also been an important part of the medium-term and long-term Integrated Urban Development Strategy of the capital city.

Concluding all the above, the historic open spaces and pedestrian streets of Budapest have been deliberately renovated, typically with the participation of landscape architects. This amounts to several hundred interventions at site level in the city [51,52]. Due to the limits on extent, the introduction of the projects is limited to a few typical, exemplary case studies in the article.

The renovated New High Street of Budapest (General design: Közlekedés Kft; Landscape design: s73 Kft-M-Teampannon $\mathrm{Kft}$ ) is an almost 3-km-long North-South axis parallel to the Danube, with vehicle traffic radically calmed and a coherent public space network appropriate to the novel role of the Downtown successfully reached. For both citizens and visitors, the High Street serves for linking, mentally as well as physically, the various character areas of the Downtown (Figures 2 and 3).

The starting point of the renovation concept is that the High Street is both a destination and a transit zone at the same time, and these two basic characters alternate along the full length of the axis. Accordingly, the principles of the renovation, which were then applied to the renovation of the whole Downtown, were the following [53]:

- Applying the principles of universal design;

- Increasing biologically active areas;

- Using quality materials based on accurate design details; and

- Functional reorganisation and distinctive pavement layout

The general message, character and effect of the axis are delivered to the users through the design details. At the same time, the professional solutions for the design issues (lighting, parking control, relation of the edge and drainage, etc.) fundamentally define the character of each street section. 

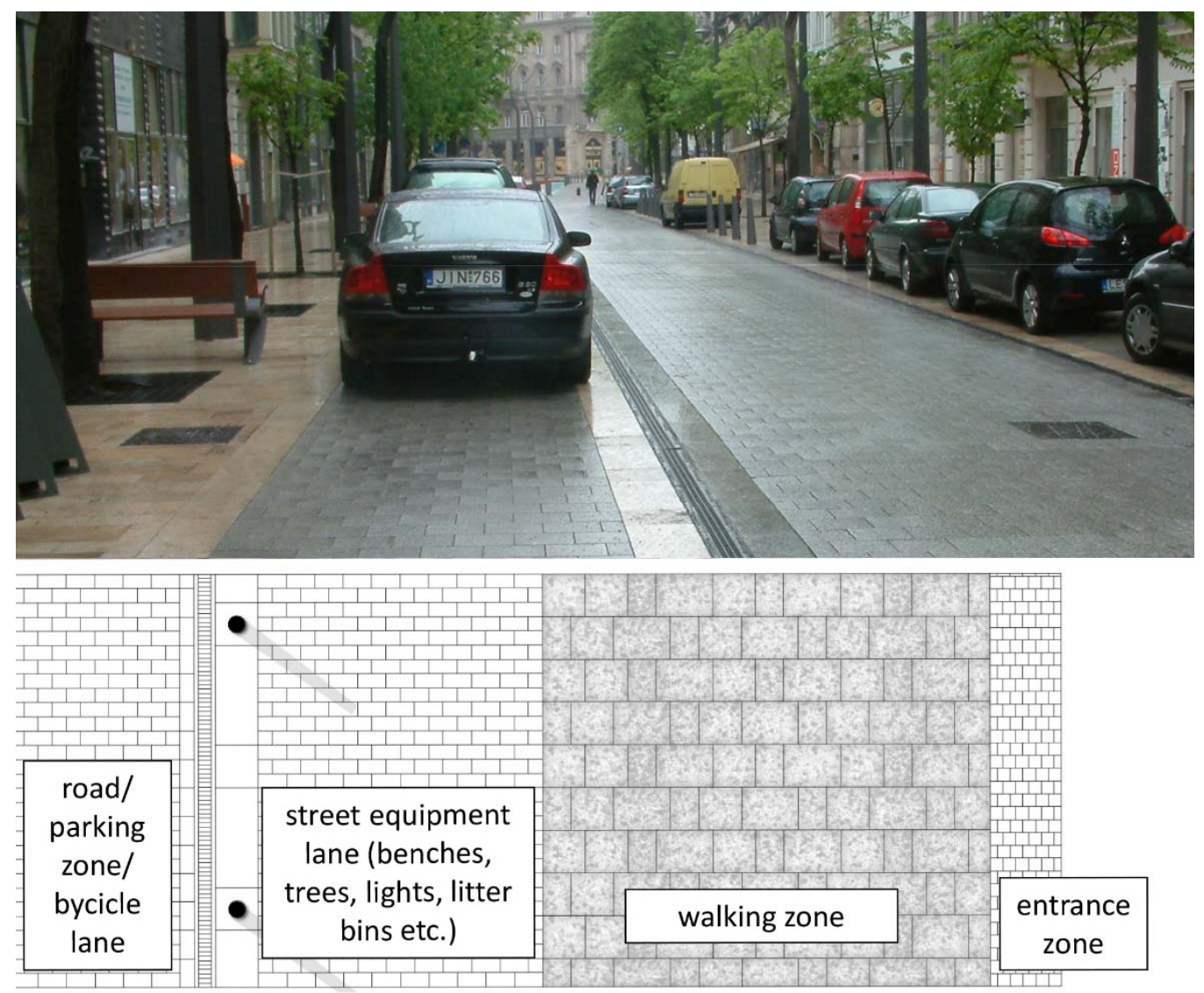

Figure 2. The pavement layout of the High Street-the plan (below) and the realised layout (above). The stones used are: granite slabs (for the areas serving for vehicle and mixed traffic or parking), limestone slabs (pedestrian and furniture zones), and the combination of the two. (Photos by the authors).
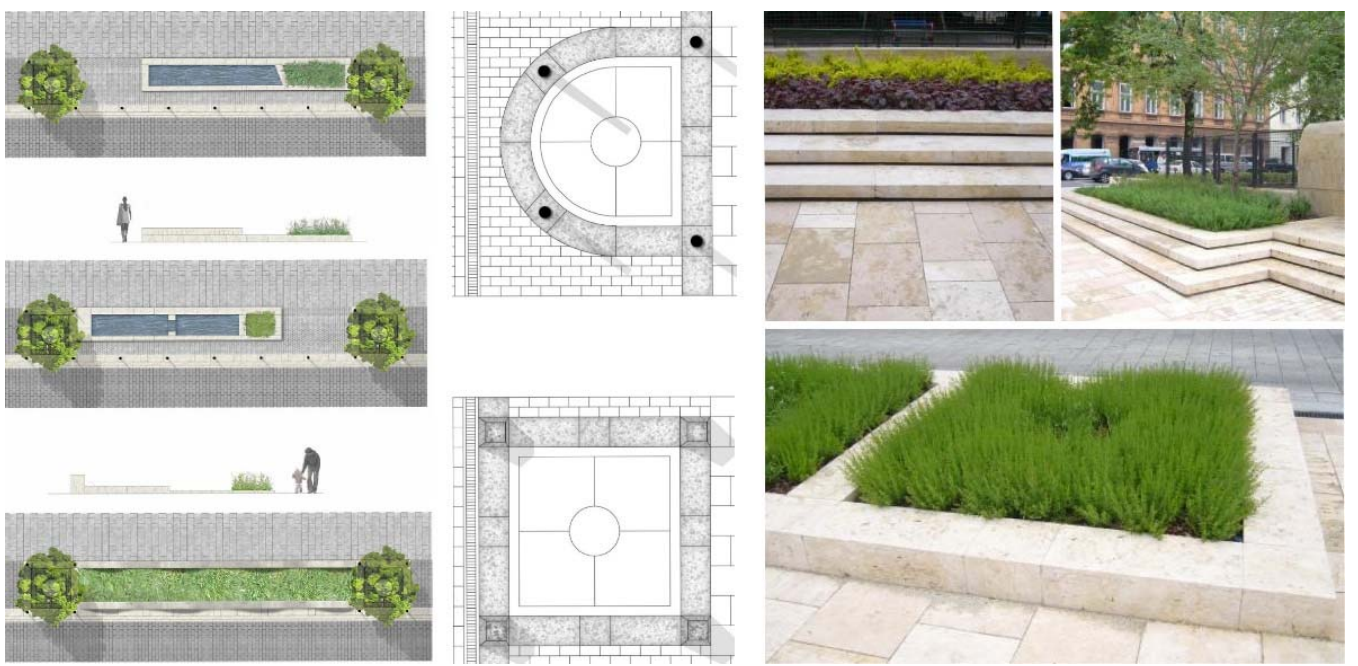

Figure 3. The limited space available and the narrow streets required several elaborate design details for the location of water features and plants. (Photos by the authors, 2012).

The High Street project marked the start of the propagation of the concept of universal design in Budapest. Since then, the principles applied first and deliberately at the High Street consequently have been determinant in the open-space design attitude, with an increasing policy support to the topic [54]. 
In the case of Kossuth Lajos Square (General design: KÖZTI Zrt; Landscape design: s73 Kft) the Building of Parliament, showing the impact of Eclecticism, with a Baroque layout and predominantly Neogothic details, is a dominant visual feature not only from the Danube riversides, but also from the direction of the square.

The main requirement on the role of Kossuth Square is to be suitable for governmental representation at both national and international levels.

The basic elements of the planning programme were the following:

- Create a square that, beyond the monumentality of the building, also suits the personal scale and relates to existing features with a modest and neat elegance;

- Provide a central location for the National Flag of Hungary, as a feature that symbolizes and connects all members of the nation;

- Reflect the democratic structure of government (openness);

- Represent and deliver the message of positive historical events of the nation at the

"Memorial Square of National History"; and

- Preserve the proportion of green space within the square.

The atmosphere of the square is characterised mostly by solemnity, modesty, receptiveness and openness (Figure 4). Regarding the composition, the square responds to the surrounding buildings through a pattern of longitudinal and lateral axes defined by and derived from the layout of the square. A clear, consequent use of plants is characteristic to the project. The completion to the existing lines of trees supports the spatial layout, providing a spatial balance. The retention of the grooves in front of the wings and at the side gardens strengthens this balance. The peaceful surfaces of lawn, and the delicate lines of hedges trimmed to blocks and stripes nicely fit the character of the square [54].

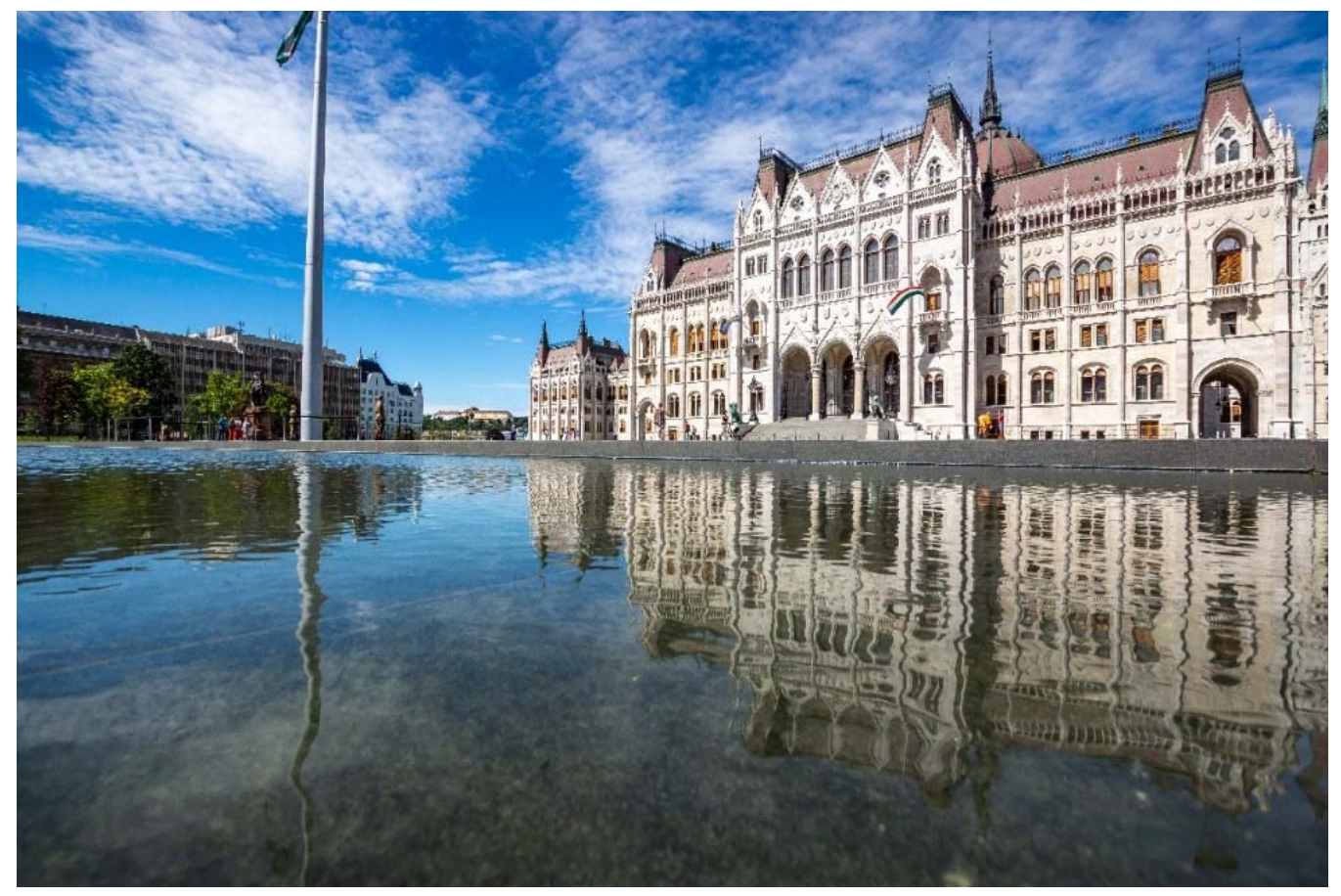

Figure 4. The water surface of the infinity-edge ornamental pool-an open central square. (Photo by the authors, 2018).

An outstanding general value of the open-space renovation is that it provides a highly sensitive urban design, responding to both the historic and spatial character of the place, without any archaic solutions. The spatial layout is clear, simple, modest. In this respect, it perfectly meets the expectations, reconstructing the threefold spatial concept of the designer Imre Steindl with contemporary, 21st century design tools. 
Széll Kálmán Square (General design: FÖMTERV Zrt; Architecture: Építész Stúdió $\mathrm{Kft}$; Landscape design: Lépték Terv Kft.) is a busy transport hub that connects the main parts of the city, Óbuda, Buda and Pest, and is therefore used by all means of public transport, vehicle and pedestrian traffic.

The concept for the open-space renovation is therefore rather traffic-oriented. The purpose of the renovation, based on national, local and EU funds, was the creation of an urban environment that is suitable to fulfill its role in the long-term, has a high architectural quality, fits well into the urban context and transport system, and is feasible and environmentally responsible (Figure 5). The principles of the renovation may be briefly summarised as follows:

- the square is neither a public park nor a promenade or leisure ground, but a transport hub;

- the square is used by more than 200,000 people daily, primarily for transfer and accessing the services (residential, commercial and tourist zones) of the adjacent areas;

- pedestrian traffic and most of the public transport take place on the surface, which makes universal design a priority and supports accessibility;

- provision of short, comfortable, all-weather and accessible pedestrian links is a must;

- the quality of the public transport must not be compromised, and none of the lines (and their users) must be adversely affected by the reconstruction of the square;

- $\quad$ opportunities for bicycle through traffic must be provided;

- the traffic system of the square must be adapted to the capacity of the incoming roads: a quick transit time of the through traffic must be ensured, and the area used by traffic must be neither reduced nor increased; and

- the square must be realised in a phased process, without any of the works taking extra time.

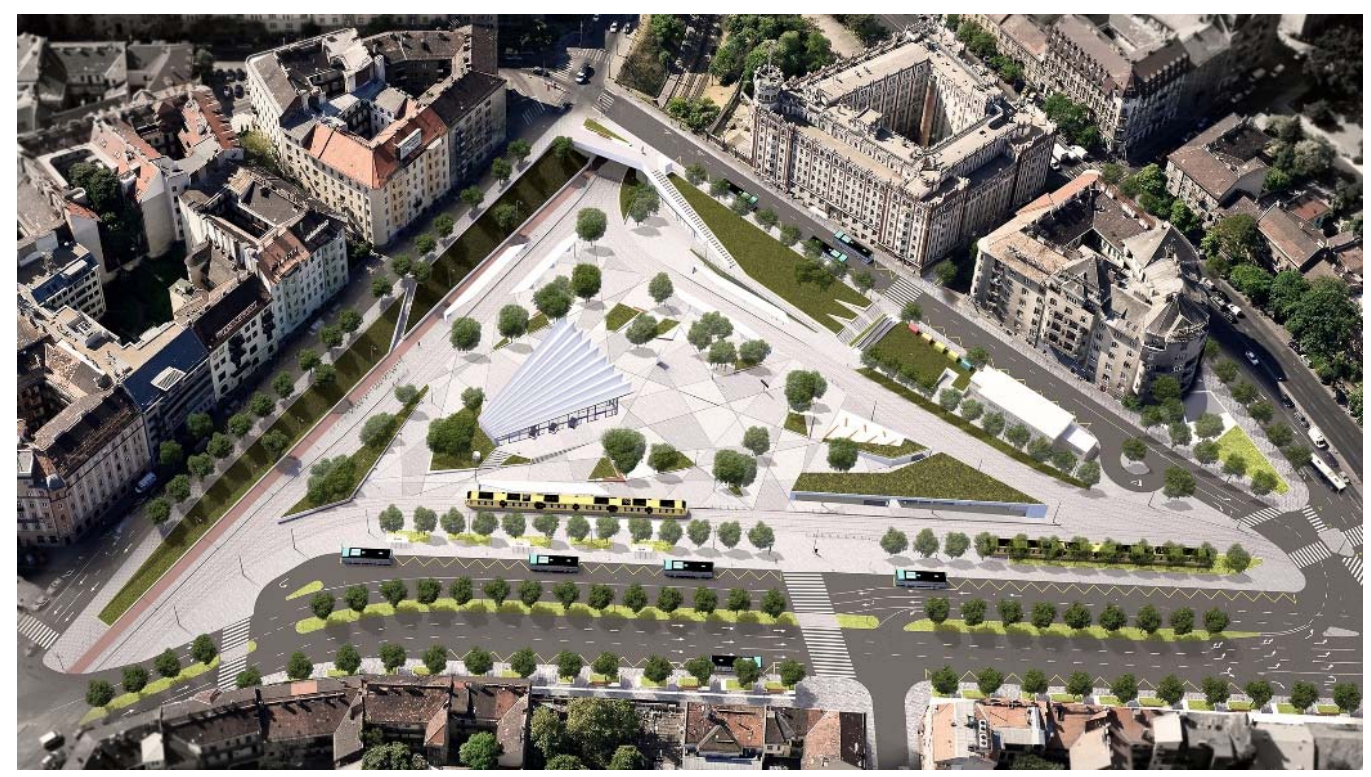

Figure 5. The open-space renovation design plan of Széll Kálmán Square.

Amongst the artistic features that determine the atmosphere of the square, the most apparent is the historic relief map in front of the glass facade at the entrance to the metro (Figure 6). The pale green and brown patterns on two angularly arranged, irregular exposed concrete walls make a composition to experience not only through the visual, but also the tactile sense (Designer: Baróthy Anna and Szövetség 39 Group). The source of the map is the ordnance survey map of Pest, Buda and Óbuda from 1823, which was an epoch-marking work of exceptionally highly qualified Habsburg ordnance surveyors. 

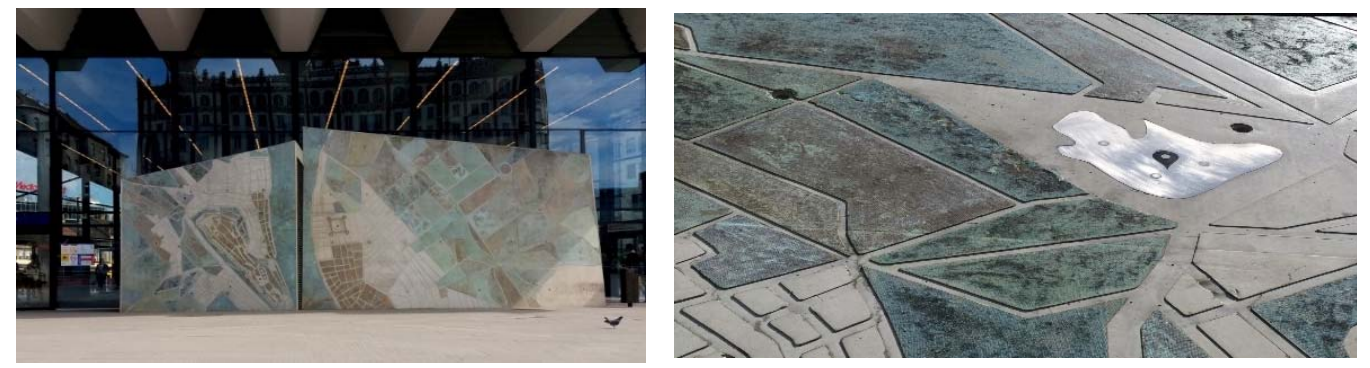

Figure 6. The two monumental units of the exposed concrete relief map (left), and a detail of the map (right) with the 1823 depiction of Széll Kálmán Square. (Photos by the authors, 2019).

The new Ditrói Mór Street promenade (Design: Lépték Terv Kft.) could form a bay along the Szent István Boulevard, providing leisure opportunities in the vicinity of the intensive traffic of the boulevard. Ditrói Mór Street is the entrance area of the theatre called Vígszínház, a meeting point before and after the plays, serving also as a site for open-air performances and exhibitions.

It is the unique design features that make this project special. The request of the client was a traditional design symbolising the world of operettas characteristic to the repertoire of Vígszínház, inspired by Hungarian folk motives. According to the concept of the designer, due to the characteristics of the urban environment of the planning site, which is one of the most cosmopolitan districts, and Eclecticism dominating its architecture, it was possible to fulfill this request only in an abstract way. Thus, the main idea of the appearance was based on the motives of Kalocsa embroidery with a simplified, minimalist and functionalist interpretation. The choice of materials was inspired by the atmosphere of the indoor space of the theatre, so theatric wine-red velvet colour stainless steel "bunting" designates each functional element along the limestone pavement of the furniture zone (Figure 7).
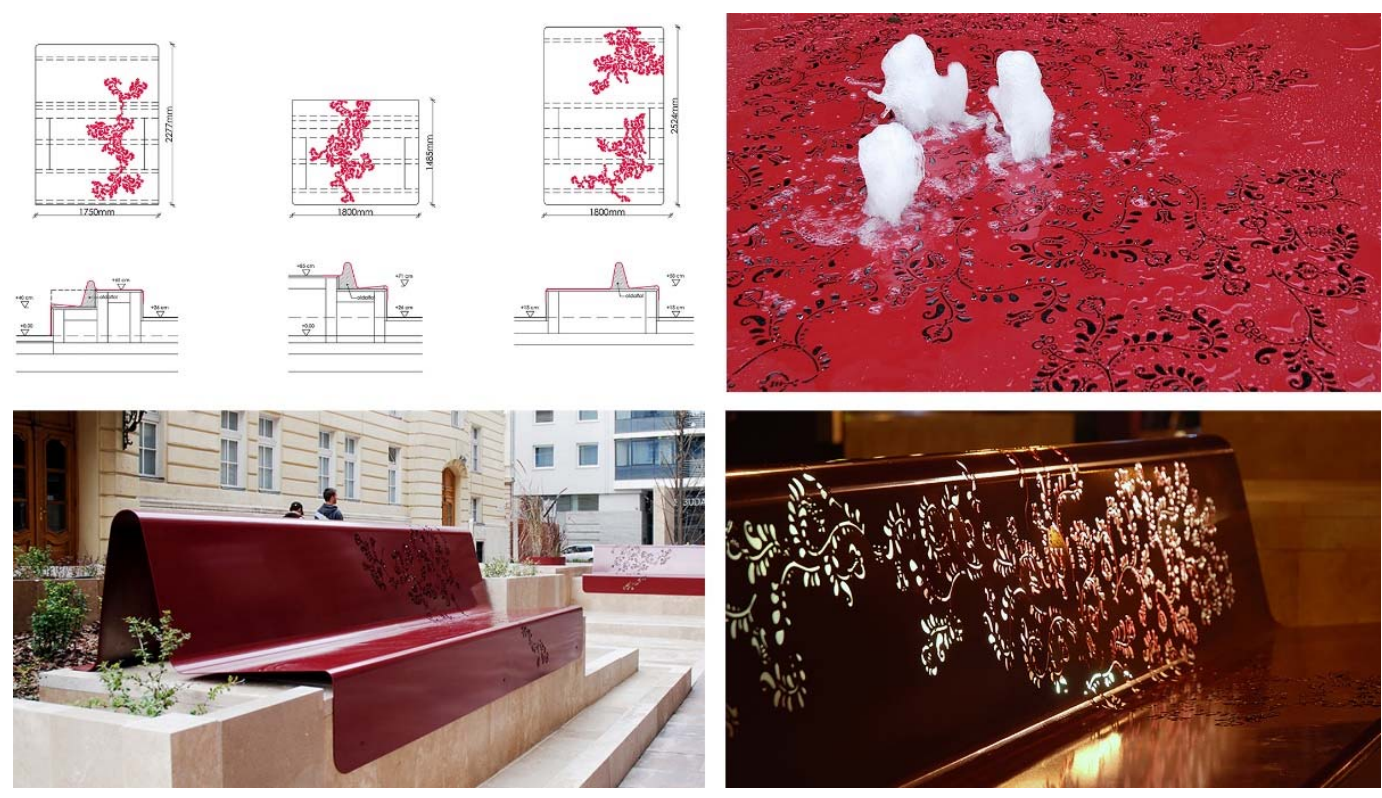

Figure 7. Design detail plans and realised elements of the unique street furniture in the Ditrói Mór street, Budapest. The unique street furniture with innovative design has multiple roles: serving as benches, and also for water features and lighting. The red steel provides a strong contrast to the white limestone slabs that are usual at Budapest public spaces, and thus a characteristic, unique design is achieved at the promenade. (Photos by authors, 2014). 


\subsection{Kraków, Poland}

In Kraków, the urban revitalisation is connected with the creation of new greeneries, based on the heritage principles, similar to the above-presented examples from Budapest. The three examples described below present the diversity of the revitalised areas in the city.

The first example, Krakowski Park was modelled after Viennese gardens and established towards the end of the 19th century. Prior to the First World War, it was one of the favourite meeting spots for the residents of Krakow. There were numerous restaurants and cafes here, in addition to a concert pavilion, a bowling alley, a swimming pool, an ice skating rink, a cycling arena, a small zoo and a pond. A summer theatre operated here as well. Initially, it had a geometric layout of a folk park with freeform elements on its edges. In 1937/38, attempts were made to remodel it to have a freeform layout (this was not completed). During the war, the park was only available to Germans occupying Poland. After the war, the pond was remodelled. The revitalization of the park was based on comprehensive conservation measures that targeted the historical garden, along with adaptation measures. The architectural design provided for the restoration of the greenery and the park furniture, and the modernization of infrastructure and lighting. The main design objective was to make the composition of park interiors and visual linkages more legible, as they had become unclear over the years. It should be highlighted that the landscaping design for Krakowski Park is the only layout of its kind in Krakow. It was developed in cooperation with "LUZ Landschaftsarchitekten München", enriching the garden with over a hectare of perennial plants. On the scale of the city, it is the largest layout to employ perennial meadows as a "leading aspect". Multi-species perennial gardens supplemented with bulb plants were designed in the outer areas of the park. Phytosociological study findings were employed, utilizing the idea of macroscale uniformity and diversity in the details. The seasonal aspect was also accounted for. The park currently features a pond that was not renovated, as well as an open-air sculpture gallery that was established in 1999 (it currently features 19 sculptures). In contrast, 130 years ago the park had a much more comprehensive functional programme. At present, new playgrounds and greenery arrangements have been introduced, attracting the city's residents (Figure 8).
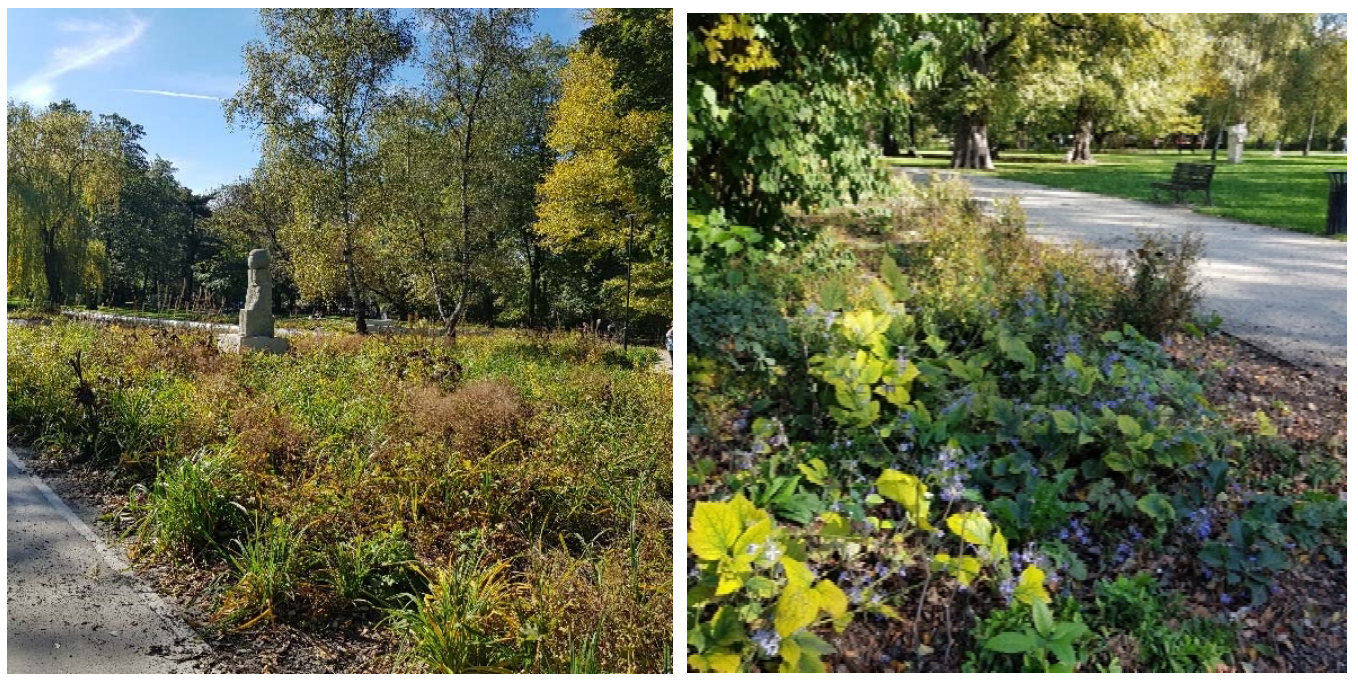

Figure 8. Krakowski Park, perennial meadows as a "leading aspect" (left), and open-air sculpture gallery (right), designer: Gajda Architektura Krajobrazu, LUZ Landschaftsarchitekten München (Photos by the Authors, 2021).

The main elements of the planning programme were the following:

- New plantings within the historic structure of the park to provide it with new quality; and 
- The improvement of the space quality with the exchange of the paths into the surfaces that enable water filtering.

The development of cities in modern times was associated with the need to extend their limits. The Planty Park, which is the subject of this study, makes up an area of ca. $21 \mathrm{ha}$, stretches $4 \mathrm{~km}$ long, and in the 19th century became an area of arranged public greenery. The parallel pathways adjust their routes to adapt to compositional changes introduced in different periods: to the classicist, landscape, naturalistic, eclectic layout, as well as to transformations carried out in the spirit of Art Nouveau, and later of Modernism. The current form is the effect of revalorisations implemented here whose goal was to improve the legibility of the observed stylistic strata. As the Planty Park is an area subject to strict protection of conservation services, the possibilities of modifications, including architectural interventions, are limited there. Generally, the Planty has not changed for years. The last investment was when two playgrounds were placed in 2017, one in the inner courtyard and the other in the eastern part of the park. The concept of a playground hidden in the yard in the vicinity of an Archaeological Museum was based on the concept of the history of human settlements. Some specific elements were built as a small garden of experiments, addressed to various age groups with special consideration for persons with disabilities. This attraction is located within less than 200 metres from the Royal Castle. The place is modern and has an original arrangement, located close to the Planty Park (a historic city ring) (Figure 9).

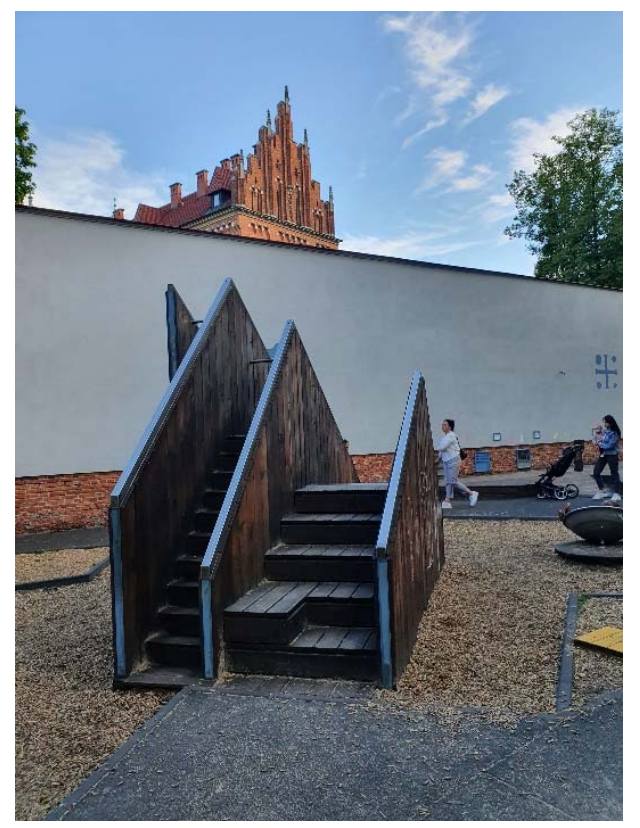

Figure 9. Planty's playground detail, Kraków, designer: Pracownia K. (Photos by the authors, 2021).

The Wilga Park, located in the south of the city, at Jana Brożka street in the 12th district, was created on the area of one of the undeveloped river parks making up a natural ecosystem along a small river with a varied level of cleanliness. The natural and ecological values of such parks were discovered at the end of the 20th century, and thus protection zones were defined. This is the first investment of such kind created with the respect for the nature and the animals that live on this area, with minimum intervention. The concept is based on the use of natural materials, the exposition of the special values of the place, appropriate for the poplar and willow riverside forest, and their adaptation for family walks and nature observations (Figure 10). The main elements of the planning programme were the following:

- The preservation of the natural character of the place; and

- Protection and re-naturalisation actions. 

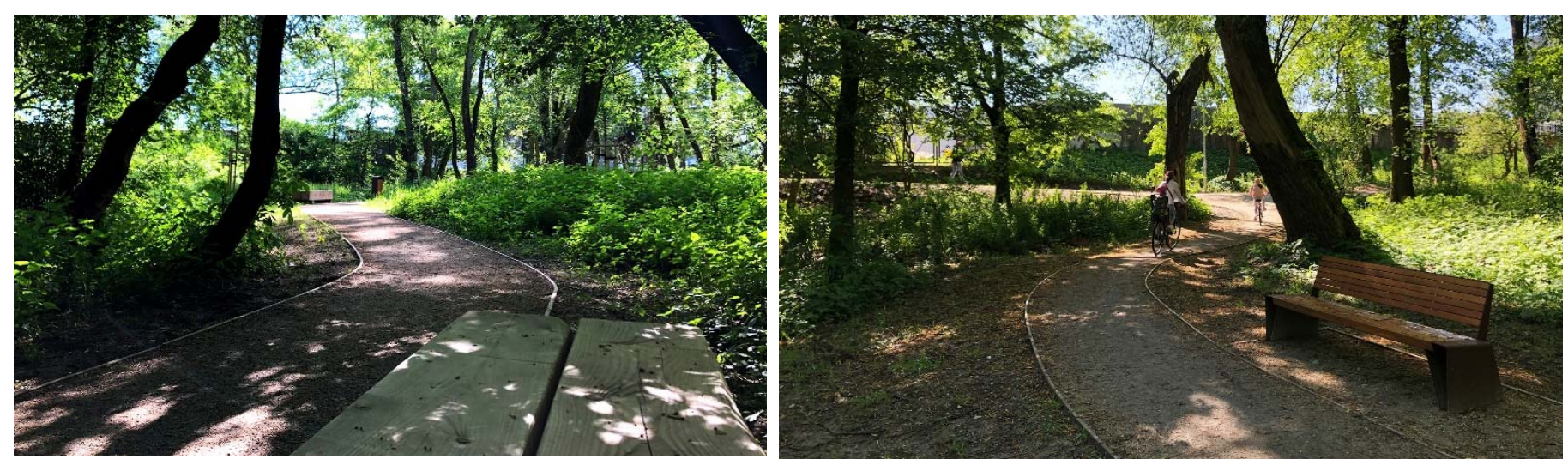

Figure 10. Wilga Park, Kraków, designer: Gajda Architektura Krajobrazu (Photos by A. Rejman, 2021).

\subsection{Shanghai, China}

The renewal of East Nanjing Road in Shanghai, China, as the main shopping and pedestrian street of the city at the end of the 1990s, was one of the first contemporary open-space design interventions in Shanghai. The East Nanjing Road Shopping Pedestrian area-running east-west in the city fabric-with a long history and high commercial value, is one of the city symbols of Shanghai. The Chinese government decided in August 1998 to start the open-space renovation, in a planned length of $1.9 \mathrm{~km}$.

The main principles of the renovation were the following:

- Re-integrate and expand the functions of East Nanjing Road and develop it into a commercial pedestrian integration of shopping, tourism, commerce, exhibition and culture;

- Organize the surrounding streets and share the traffic pressure of East Nanjing Road, which lay the foundation for Nanjing East Road to become a large-scale pedestrian block;

- Integrate the open space of the pedestrian street with the buildings and the neighborhoods on both sides of the road. Extend it to the branch road and develop in a herringbone shape; and

- Apply the livable city concept in the renewal; coordinate the facilities with people and building scales to create an urban space environment suitable for recreation and social connections (Figure 11).

According to the analysis of the characteristics of crowded shopping behavior, an asymmetric layout is adopted, with a $4.2 \mathrm{~m}$ wide "golden belt" as the main line. Urban public facilities (seats, shopping pavilions, billboards, sculptures, street lightings, flower beds, etc.) are arranged on the "golden belt", making it a recreational space for pedestrians [55].

For example, the regeneration of Middle Jiangxi Road in 2019 integrates some timehonored business with innovative elements, making it a gathering place for popular old-brand stores. The renovation extends to the branch roads on both sides, explores the cultural characteristics of the branch roads, and transforms some of those into characteristic pedestrian features. In this way, a herringbone shape has been developed, forming East Nanjing Road as a pedestrian block.

The regeneration of the open-space system alongside of Shanghai Southern Yangpu Waterfront is a recent project in Shanghai, dating from 2015. The municipality developed a 3-year program for a better connection of the Huangpu River shoreline with the city in the downtown area, creating a continuous pedestrian zone and leisure for the city.

Both the Huangpu River and Suzhou River represent two of the most distinctive, representative and symbolic landmarks of Shanghai. The vacant buildings and abandoned docks there from the post-industrial era prevented people from entering the river and also cut off the walking flow along the river. These, however, are precious historical memories of the city (Figure 12). 


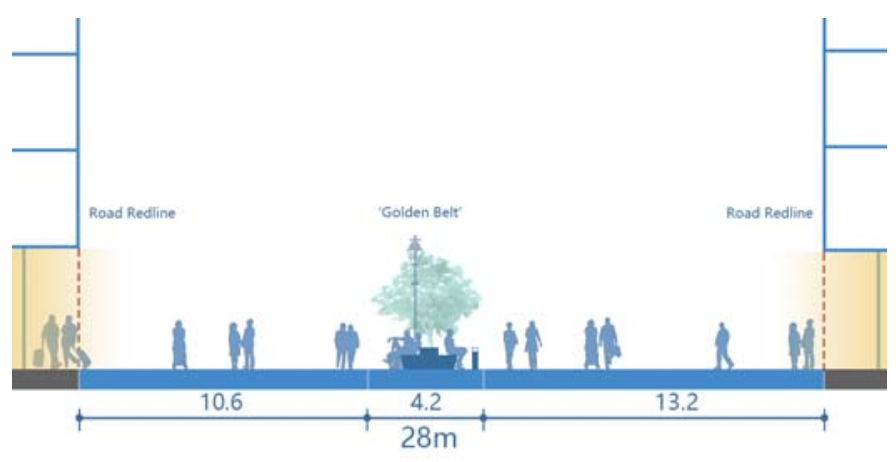

(a)

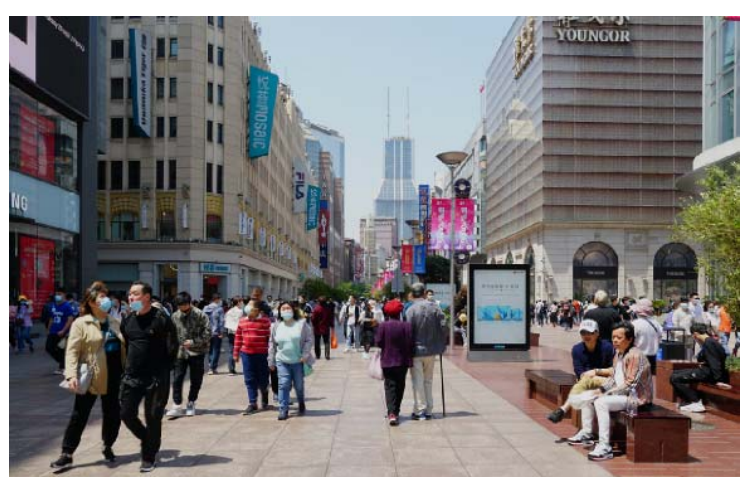

(b)

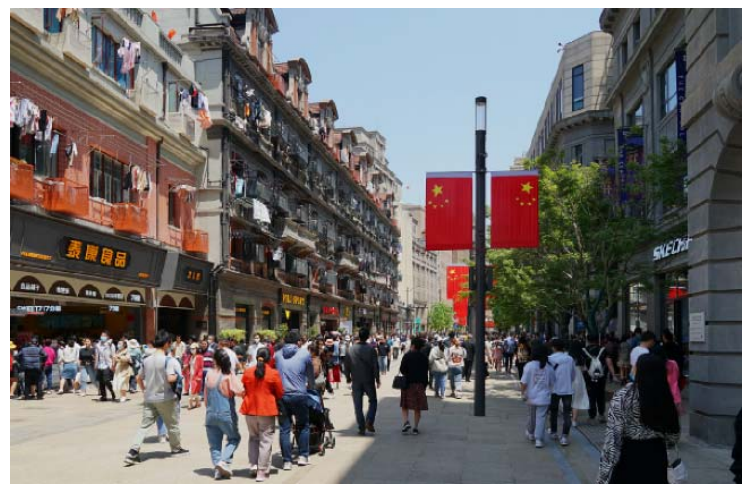

(c)

Figure 11. Section of the pedestrian street (a), the "golden belt" (b) and the renewal in 2019 (c). Source (a): drawn by Li Yu; source (b,c): photo by Li Yu, 2021.

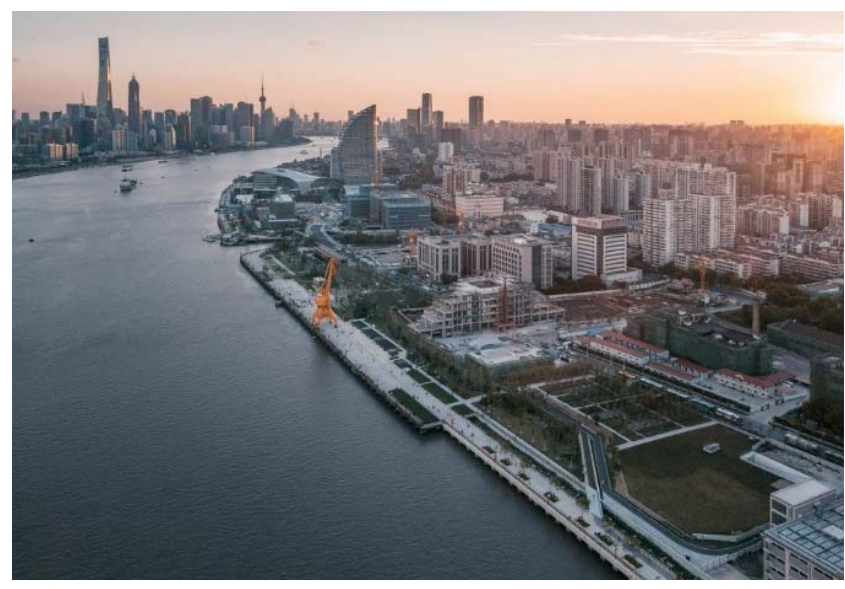

(a)

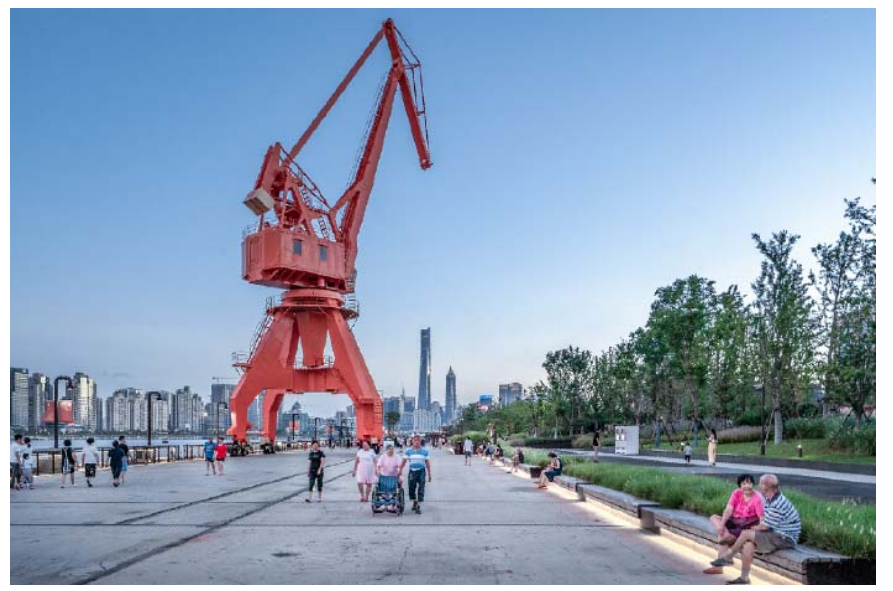

(b)

Figure 12. Connected shoreline in the downtown area of the Huangpu River (a); the dock crane was completely retained as a new visual focus (b) Source (a,b): DA Landscape, Photographer: Jin Xiaohui.

For instance, the Yangpu Riverfront South Section, designed by DA Landscape, created a circulation system called "3-WAYS", which is a hybrid greenway system including walking, jogging and cycling paths. The 3-WAYS model is a very successful design tool in the reopening of closed riverfront space. By the elevated pedestrian bridges or trails, all breakpoints such as ferry stations, tributary rivers, and specially designated land are linked to create a continuous circulation.

The design of the linked open spaces of the riverfront focuses on both the collaborative protection of historical texture and ecological restoration. This also adds new functions to enhance its vitality and become new hotspots (Figure 13). 


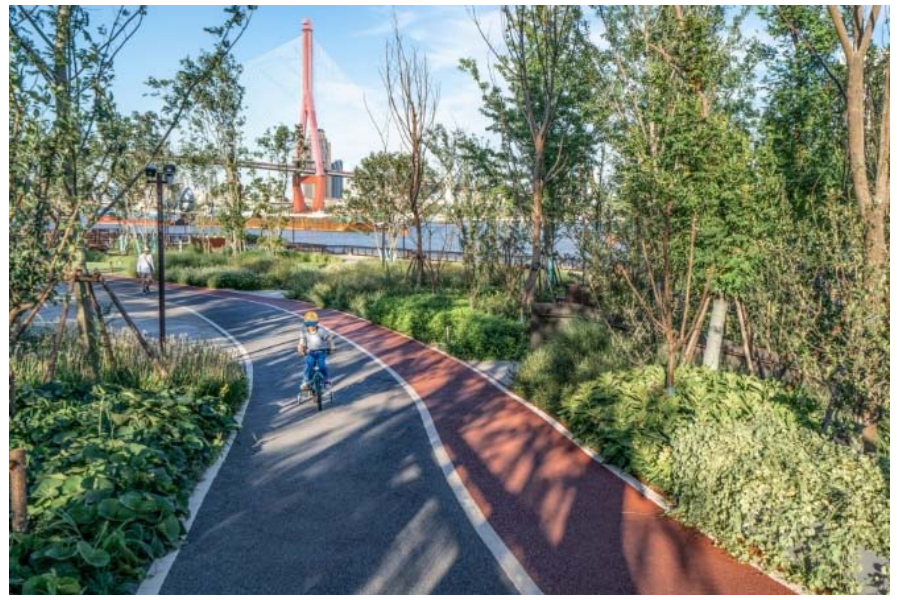

(a)

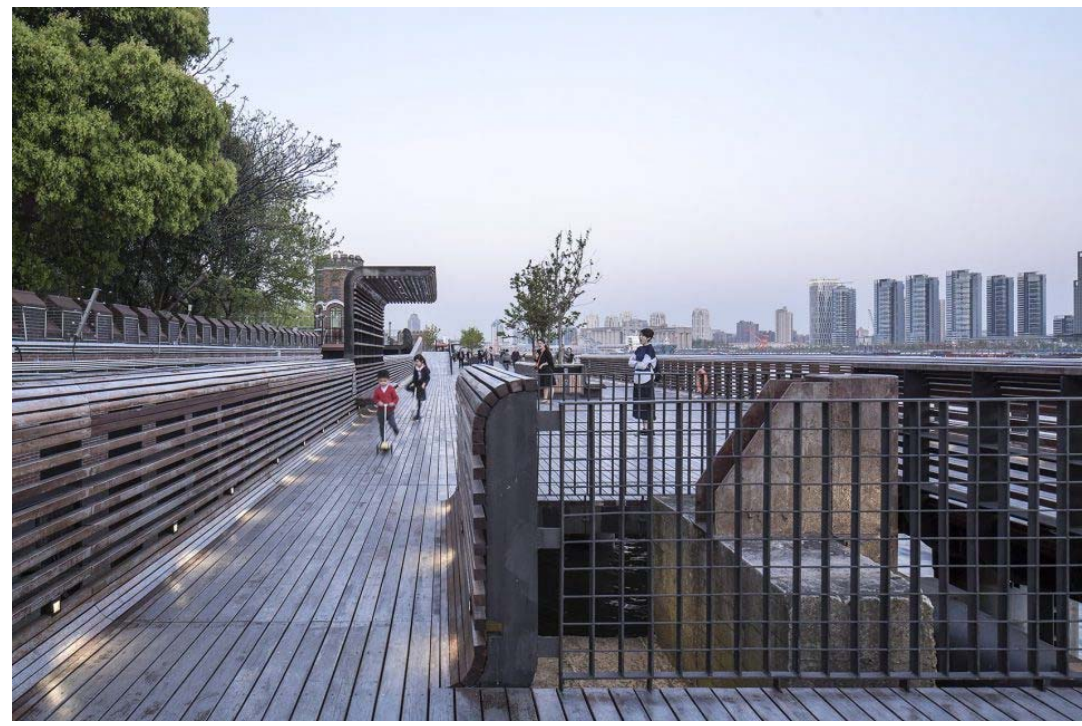

(c)

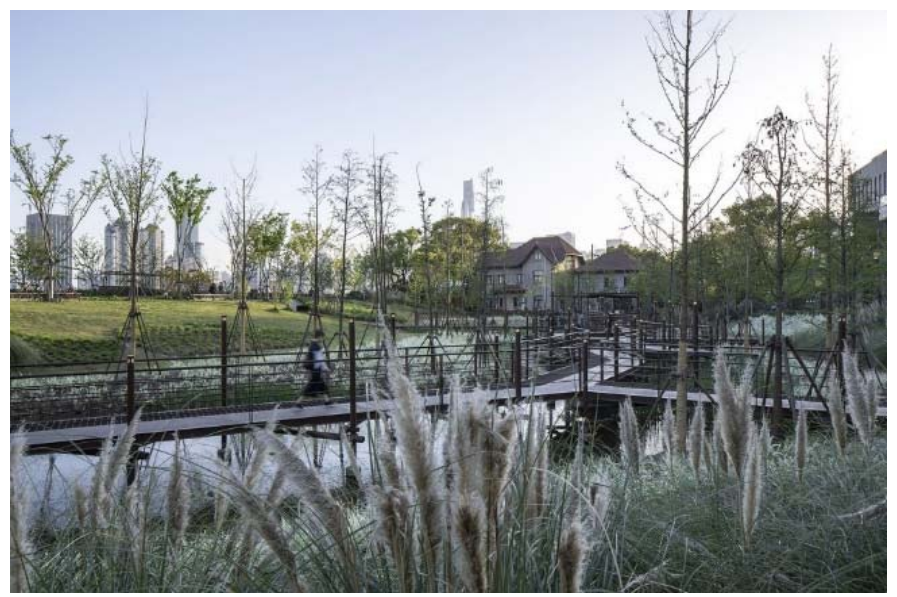

(e)

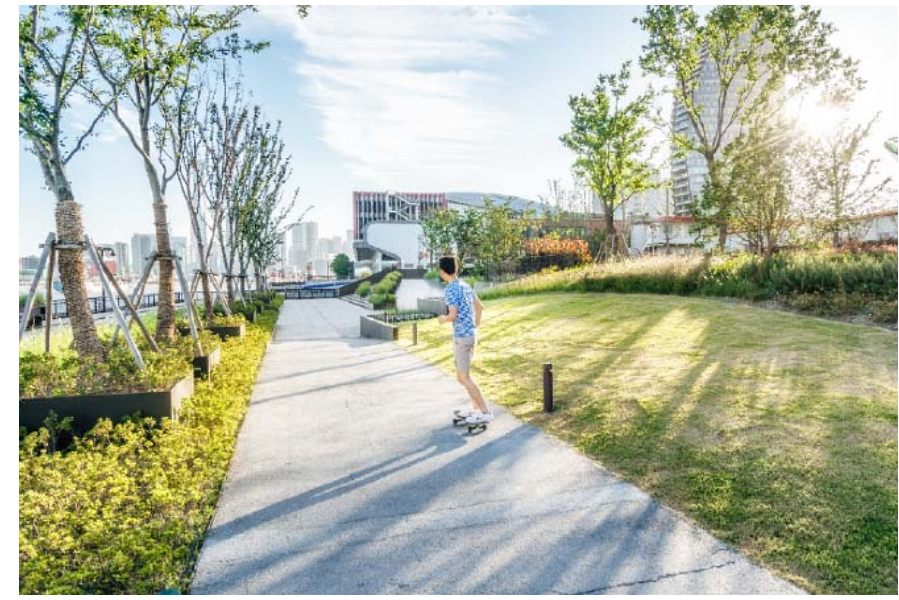

(b)

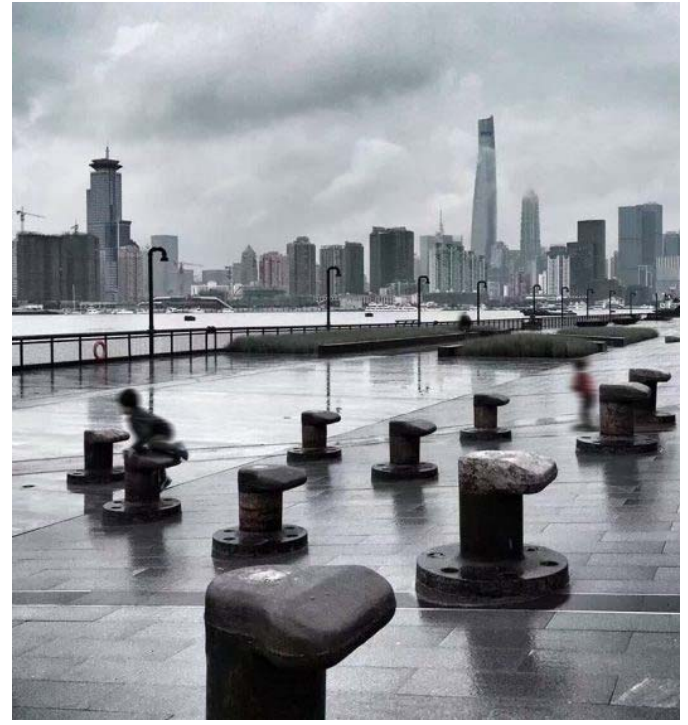

(d)

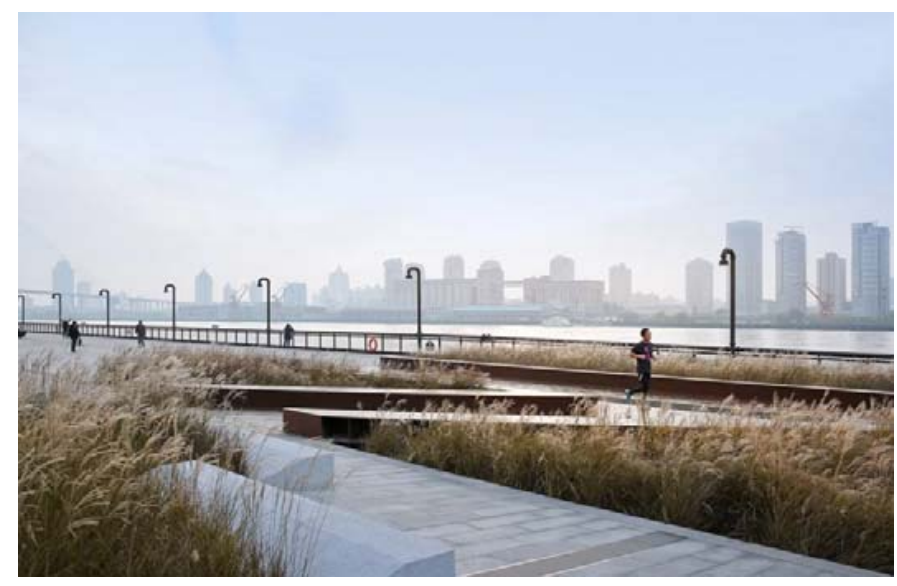

(f)

Figure 13. Jogging, cycling and walking ways alongside Huangpu River (a,b); an array of preserved moorings as the main landscape factor for a plaza; the preserved mooring structure in front of the water plant (c,d); wetland, passageway and preserved historical building (e); landscape with natural features (f) Source: (a,b) DA Landscape, Photographer: JIN Xiaohui; source (c-f): TJAD Original Design Studio, Photographer: ZHANG Yong $\backslash$ SU Shengliang. 
The first phase of the Yangpu Riverfront South Section design by TJAD Original Design Studio, located between two ferry stations on the Huangpu River, is called the Yangpu Riverfront Demonstration Section. The design strategy is to keep and reuse the industrial structures. All high-pile wharfs were retained and reused, and a 10-ton dock crane was completely retained as a new visual focus, reducing construction costs. Moreover, scratches and textures were left on the old wharf to spatialize and materialize the memories. Instead of natural granite, precast concrete or cast-in-place concrete as the finish, and colored asphalt were used, which is close to the texture of the old dock and brings a holistic and continuous paving effect. The designer also adopted the strategy of limited intervention and low-impact development. Ecological restoration and transformation were carried out while respecting the original site conditions.

\section{Conclusions}

Open space design, as an integral part of urban design, is the art of relationship. The duty is therefore to explore new, hidden relationships or strengthen existing ones that provide a visual urban experience, unveiling the values and characteristics of the specific place to the spectator.

The character of the cities under review reflects a special planning approach: with an urban development strategy focused on the sale of properties, until the 21st century, little attention was paid to open-space design solutions that would have a positive effect on the character.

The original role of urban open spaces has significantly been extended, their uses and functions substantially evolved and renewed (representation, socialisation, commercial, cultural and living space, visual effects, traffic, leisure and garden). At the same time, the planning methodology of urban open spaces has also changed, the role of the planner having become more complex. The main reason for that is that the planning process needs multiple actors. In addition to the client and the planner, the users also actively contribute to the planning process (participatory planning), so that their needs can more directly shape the public places. Moreover, local governments, other professionals concerned, public utility providers, planning and other relevant authorities (e.g., cultural heritage conservation, nature conservation), NGOs (e.g., bicycle associations, associations for blind people), contractors, park managers and others also participate and comment on the plan. The legal background for planning is also becoming more rigid and complex, so that a consensus is more difficult to achieve. The final result then must have the agreement of all participants, which requires a comprehensive coordination based on a complex approach from the landscape architect as the general planner.

- The renovation of open spaces in Budapest is an important part of the mediumterm and long-term Integrated Urban Development Strategy of the capital city. It significantly expands the function and enriches the role of historic urban open spaces, contributing to the overall development of the city. In China, although there are some practices as good examples, generally the importance of historic open spaces to urban regeneration and development is ignored. The Budapest experiences show us the potential that historic open spaces can be an approach and/or catalyst of the Chinese urban regeneration;

- The renewal of the historic open spaces in the center of Kraków and Budapest is carried out under an integrated framework and a unified goal—development-oriented heritage conservation with respect to the unique urban character and preserved historic value. Beyond a sensitive approach to heritage conservation and design, these cases also attach great importance to local identity, culture and art creation, interactions between the surroundings and the historical buildings, public participation and sustainability. They illustrate detailed design strategies of how to turn the urban historic open spaces into attractive and functional places, and these will be very helpful to Chinese practices; 
- The renovation of open spaces also has important economic aspects, especially in a historic environment. The average cost of open-space renovations in the inner city was around HUF 150,000/square $m$ in the construction period of the examples introduced. This number is interesting to compare to the directive of the National Development Agency on renovation of public spaces, which assigned a maximum of HUF 50,000/square m net price as the cost for "priority public space renovations" supported from EU funds. This means that high-quality open-space renovations are not possible to realise from the EU budget only. Beyond the use of EU money, most of the projects required significant contributions from local resources (double the amount of what the EU fund covered); and

- The general tendency of the development of open spaces in Budapest, Kraków and Shanghai is clearly positive. However, for having a successful and result-oriented open-space design in the future, it would be important to clarify the problematic issues, especially the pitfalls related to the management of public transport, the status of public utilities, and the uses of surface areas. A distinction is necessary between public spaces and "public spaces of modified status" (terminals, bus stops, platforms, traffic islands and containers of public utilities). Furthermore, optimising the uses, integrating the traffic into the everyday life of the public space as much as possible, are crucial so that a successful renovation of open spaces is possible to achieve.

Although the case studies introduced are rather different in their urban integration and design, they are related by the basic concept of their renovation, which can be described as the ideology behind 21st century open-space renovations. This means that open-space renovation may respond to the historic environment diversely, but architectural heritage must always be respected. Although historic periods may be evoked, copies of bygone eras that had never existed at the specific location should never be applied.

Author Contributions: Conceptualization, A.F. and D.D.; methodology, A.F.; software, D.D.; validation, A.F., D.D. and K.H.; formal analysis, K.H.; investigation, A.F., D.D. and K.H.; resources, A.F., D.D. and K.H.; data curation, A.F., D.D. and K.H.; writing-original draft preparation, A.F.; writing-review and editing, A.F., D.D. and K.H.; visualization, A.F., D.D. and K.H.; supervision, A.F., D.D. and K.H.; project administration, A.F.; funding acquisition, A.F., D.D. and K.H. All authors have read and agreed to the published version of the manuscript.

Funding: This research received no external funding.

Institutional Review Board Statement: Not applicable.

Informed Consent Statement: Written informed consent has been obtained from the patient(s) to publish this paper.

Data Availability Statement: Not applicable.

Conflicts of Interest: The authors declare no conflict of interest.

\section{References}

1. Clark, K. Power of place-heritage policy at the start of the new millennium. In The Historic Environment: Policy E Practice; Taylor \& Francis: Abingdon, UK, 2019; Volume 10, pp. 255-281.

2. Nijhuis, S.; van Lammeren, R.; van der Hoeven, F. Exploring the Visual Landscape-Advances in Physiognomic Landscape Research in the Netherlands; IOS Press: Amsterdam, The Netherlands; Delft University Press: Amsterdam, The Netherlands, 2011.

3. Varna, G.; Tiesdell, S. Assessing the publicness of public space: The star model of publicness. J. Urban Des. 2010, 15, 575-598. [CrossRef]

4. Southworth, M. Designing the walkable city. J. Urban Plan. Dev. 2005, 131, 246-257. [CrossRef]

5. Ehrenhalt, A.; The Empty Square. Preservation March/April 2000, 42-51; National Trust for Historic Preservation: Washington, DC, USA.

6. Ashihara, Y. The Aesthetic Townscape; MIT Press: Cambridge, MA, USA, 1983.

7. Short, J.R.; Kim, Y.H. Globalization and the City; Addison Wesley Longman Ltd.: Harlow, UK, 1999.

8. Bardóczi, S. Three Lines-Three Years [Három Vonal-Három Év]. Available online: https://epiteszforum.hu/harom-vonalharom-ev (accessed on 24 May 2020). (In Hungarian) 
9. ICOMOS MNB. Preservation and Development of Values [Az értékek megőrzése és továbbörökítése]. Available online: http: //www.icomos.hu/index.php/hu/data/documents/documents/9/9/b/99bb00d0abb25fcb1926d82cd7f58e9f.pdf (accessed on 20 May 2020). (In Hungarian)

10. Zheng, H.T.; Zhang, Y.R. A comparative analyzis of the urban renewal studies in China and foreign countries: Based on bibliometrics. City Plan. Rev. 2017, 41, 111-121.

11. Zhou, J.; Yan, S.; Wan, Z. Reflections on improving the urban renewal system of Shanghai. Urban Plan. Forum 2019, 1, 20-26.

12. Huang, Y.; Wu, C. Exploration on China's community planning based on urban regeneration and urban governance: Practice of Jinyang New Village Community in Pudong New area of Shanghai. Urban Dev. Stud. 2020, 27, 110-118.

13. Zheng, S. Urban regeneration and conservation of historic architecture. Bull. Chin. Acad. Sci. 2017, 32, $690-695$.

14. Xiaoming, K. Research on the difficulties and countermeasures of urban renewal in Shanghai. Sci. Dev. 2017, $03,32-39$.

15. Yang, R.; Yuan, L.; Zheng, X. Relationship between landscape architecture and urban design. Chin. Landsc. Archit. 2016, 32, 37-42.

16. Zheng, S. Shanghai urban space art season: Towards the total art. Architecture 2020, 1, 54-57.

17. Mannberg, M.; Wihlborg, E. Communicative planning-Friend or foe? Obstacle and opportunities for implementing sustainable development locally. Sustain. Dev. 2008, 16, 35-43. [CrossRef]

18. Ahern, J. Green infrastructure for cities: The spatial dimension. In Cities of the Future Towards Integrated Sustainable Water and Landscape Management; Novotny, V., Brown, P., Eds.; IWA Publishing: London, UK, 2007.

19. Jongman, R.H.G.; Külvik, M.; Kristiansen, I. European ecological networks and greenways. Landsc. Urban Plan. 2004, 68, 305-319. [CrossRef]

20. Swaffield, S. Shaping an urban landscape strategy to promote biodiversity. In Greening the City: Bringing Biodiversity Back into Urban Environment, Proceeding of the Conference of the Royal New Zealand Institute of Horticulture, Christchurch, New Zealand, 21-24 October 2003; Dawson, M., Ed.; Lincoln University: Christchurch, New Zealand, 2005; pp. 246-260.

21. Sukopp, H.; Wurzel, A. The effects of climate change on the vegetation of central European cities. Urban Habitats 2003, 1, 66-86.

22. Meurk, C.; Swaffield, S. Cities as complex landscapes: Biodiversity opportunities, landscape configurations and design directions. N. Z. Gard. J. 2007, 10, 10-20.

23. Roehr, D. Influence of Western landscape architecture on current design in China. In Globalisation of Landscape Architecture: Issues for Education and Practice; Stewart, G., Ignatieva, M., Bowring, J., Egoz, S., Melnichuk, I., Eds.; St. Petersburg's State Polytechnic University Publishing House: St. Petersburg, Russia, 2007; pp. 166-170.

24. Zhang, S. From the protection of historical and cultural cities to the protection of built heritage. China Anc. City 2019, 5, 4.

25. Urban Design Manual a Best Practice Guide. A companion document to the Guidelines for Planning Authorities on Sustainable Residential Development in Urban Areas. Environment, Heritage and Local Government, Ireland. Available online: https: //www.opr.ie/wp-content/uploads/2019/08/1999-Urban-Design-Manual-1.pdf (accessed on 1 July 2021).

26. Shaftoe, H. Convivial Urban Spaces: Creating Effective Public Places; Earthscan: London, UK, 2008.

27. Nasar, J.L. Perception, cognition, and evaluation of urban places. In Public Places and Spaces; Plenum Press: New York, NY, USA, 1989; pp. 31-56.

28. Massengale, J.M.; Dover, V. Street Design: The Secret to Great Cities and Towns; John Wiley \& Sons, Inc.: Hoboken, NJ, USA, 2014.

29. Mehta, V.; Bosson, J.K. Third Places and the Social Life of Streets. Environ. Behav. 2010, 42, 779-805. [CrossRef]

30. Mehta, V. The Street: A Quintessential Social Public Space; Routledge: Abingdon, UK; New York, NY, USA, 2013.

31. Von Meiss, P. Elements of Architecture: From Form to Place; Chapman \& Hall: London, UK, 1990.

32. Gehl, J. Cities for People; Island Press: Washington, DC, USA, 2010.

33. Gehl, J. Life between Buildings, Using Public Space; Island Press: Washington, DC, USA, 2011.

34. Gehl, J.; Svarre, B. How to Study Public Life; Island Press: Washington, DC, USA, 2013.

35. Gehl, J.; Gemzøe, L. Public Spaces, Public Life; Danish Architectural Press and the Royal Danish Academy of Fine Arts, School of Architecture: Copenhagen, Denmark, 1996.

36. MacGowan, T. Green square. Landsc. Archit. Aust. 2008, 119, $26-27$.

37. Walmsley, A. Greenways and the making of urban form. Landsc. Urban Plan. 1995, 33, 81. [CrossRef]

38. Carmona, M.; Tisdell, S.; Heath, T.; Oc, T. Public Places, Urban Spaces: The Dimensions of Urban Design, 2nd ed.; Elsevier: Oxford, $\mathrm{UK}, 2010$.

39. Carr, S.; Francis, M.; Rivlin, L.G.; Stone, A.M. Public Space; Cambridge University Press: New York, NY, USA, 1992.

40. Madanipour, A. Public and Private Space of the City; Routledge: London, UK, 2003.

41. Cullen, G. The Concise Townscape; The Architectural Press: London, UK, 1971.

42. Camillo, S.; Collins, C.C.; Collins, G.R. Camillo Sitte: The Birth of Modern City Planning: With a Translation of the 1889 Austrian Edition of his City Planning According to Artistic Principles; Rizzoli: New York, NY, USA, 1986.

43. Christopher, A.; Ishikawa, S.; Silverstein, M. A Pattern Language: Towns, Buildings, Construction; Oxford University Press: New York, NY, USA, 1977.

44. Finta, S. Budapest 2030. Long Term Development Concept [Budapest 2030. Hosszútávú fejlesztési koncepció.] Budapest Főváros Főpolgármesteri Hivatal Városépítési Főosztály, Budapest, Hungary. Available online: https://budapest.hu/Documents/V\%C3 \%A1ros\%C3\%A9p\%C3\%ADt\%C3\%A9si\%20F\%C5\%91oszt\%C3\%A1ly/Budapest2030_HUN_\%C3\%B6sszefoglal\%C3\%B3.pdf (accessed on 8 May 2020). (In Hungarian) 
45. City of Cracow. Rewitalizacja Obszarów Miejskich. Available online: https://www.bip.krakow.pl/?sub_dok_id=944 (accessed on 10 May 2021). (In Polish)

46. Zhang, A. Address urban regeneration challenge with temporary creative uses: The case of Beijing's Dashilar area. In Transforming Cities through Temporary Urbanism: A Comparative International Overview; Andres, L., Zhang, A., Eds.; The University of Manchester Research, Springer Nature, 2020. Available online: https://www.research.manchester.ac.uk/portal/files/182357517/Zhang_2021 _Temporary_creative_use_Beijing.pdf (accessed on 2 July 2021).

47. DA Landscape + TJAD Original Design Studio. Yangpu Riverfront South Section Phase II. Available online: https://www. archdaily.com/916769/yangpu-riverfront-south-section-phase-ii-da-landscape (accessed on 14 March 2021).

48. Metropolitan Research Institute Budapest. The Podmaniczky Programme. Medium-Term Urban Development Programme of Budapest. Available online: http:/ / www.varosrehabilitacio.net/new/pdf/Podmaniczky_Program.pdf (accessed on 18 May 2020).

49. Finta, S. TÉR-KÖZ an Urban Rehabilitation Design Competition [TÉR_KÖZ városrehabilitációs pályázat]. Available online: http:/ / terkoz.budapest.hu/ (accessed on 18 May 2020). (In Hungarian)

50. Budapest Dialog. In Dialogue with the City [Párbeszédben a várossal]. Available online: https://www.budapestdialog.hu/ (accessed on 20 May 2020). (In Hungarian)

51. Bardóczi, S.; Dér, A. (Eds.) 2010: Landscape Odyssey—Catalogue of the Most Important Landscape Architectural Projects in Hungary 2000-2010 [2010: Tájodüsszeia. Katalógus a magyar tájépitész szakma 2000-2010 közötti legfontosabb alkotásaiból]; Hungarian Association of Landscape Architects: Budapest, Hungary, 2010; pp. 1-166.

52. Bardóczi, S. (Ed.) 2015: Landscape Odyssey_Landscape Architecture in Hungary, the Most Significant Projects and Artworks 2010-2015 [2015: Tájodüsszeia. Katalógus a magyar tájépitész szakma 2010-2015 közötti legfontosabb alkotásaiból]; Hungarian Association of Landscape Architects: Budapest, Hungary, 2015; pp. 1-344.

53. Balogh, P.I.; Koszorú, L.; Mohácsi, S. From ordinary streets to main street. The new Main street program of central area of Pest [Utcákból főutca. A pesti belváros új Főutca programja]. 4D J. Landsc Archit. Gard. Art 2008, 9, 4-17. (In Hungarian)

54. Fekete, A.; Planchat, S.; Szöbölödi, A.; Takács, D. Accessibiliy analyzis of contemporary open spaces in Budapest [Kortárs szabadtérépítészeti alkotások akadálymentességének elemzése Budapest belvárosában]. In Fenntartható Fejlődés, Élhető Régió, Élhető Települési Táj; Csemez, A., Ed.; Budapesti Corvinus Egyetem: Budapest, Hungary, 2009; Volume 3, pp. 131-141. Available online: https:/ / s73.hu/kossuth-lajos-ter (accessed on 28 May 2020). (In Hungarian)

55. Zhou, S.; Yan, W.; Liu, Y.; Meng, H. The Design of Nanjing Road pedestrian mall in Shanghai. N. Archit. 2001, 3, 1-5. 